\title{
Influence on Financial Literacy of Regional Differences in Income and Activity of Using DFS
}

\author{
Razumovskaya E.A. ${ }^{1,2,{ }^{*}}$ Razumovskiy D.Yu. ${ }^{3,4}$ \\ ${ }^{1}$ Ural Federal University named after the first President of Russia B.N. Yeltsin \\ ${ }^{2}$ Ural State University of Economics \\ ${ }^{3}$ Ural Federal University named after the first President of Russia B.N. Yeltsin \\ ${ }^{4}$ Ural State University of Economics \\ *Corresponding author. Email: rasumovskaya.pochta@gmail.com
}

\begin{abstract}
The article presents some results of the analysis of the influence of regional differences in incomes and people's activity in using digital financial services (DFS) on the financial literacy of the population. The authors proceeded from the hypothesis of the approximation of the effect of concentration of financial activity in large federal centers of the Russian Federation on other territories, in particular, the Sverdlovsk region. The main research hypothesis is, that the regular and active use of digital financial services is more essential to people living in large settlements and having a relatively higher income; these two factors have a decisive influence on the level of financial literacy. The use of constantly developing digital financial services in everyday life allows people to visualize the dynamics of their financial capabilities, analyze and adjust the structure of financial resources based on its results, which increases financial knowledge and strengthens skills. As a goal, the authors pursued the possibility of confirming and verifying the influence of regional differences in income and the activity of using digital financial services on the level of financial literacy of residents of the Sverdlovsk region. The study was carried out by the method of sociological survey on the questionnaires, developed by the authors, based on the methodology of the Central Bank of the Russian Federation and the OECD.
\end{abstract}

Keywords: financial literacy, household financial resources, digital financial services

\section{INTRODUCTION}

Socially oriented research is being updated under conditions of economic instability, therefore, the not completely overcome consequences of geopolitical tensions and the 2014 devaluation shock, the overcoming of which is associated with the need to restore the most important financial and economic criteria of the state of the national economy of the Russian Federation, predetermined the need to study the factors, affecting the financial behavior of the population. The authors categorized as the most important financial and economic indicators: gross domestic product (GDP), real incomes of the population, the rate of dynamics of the industrial production, investments and consumer activity, which determine the dynamics of the retail sector (figure 1).

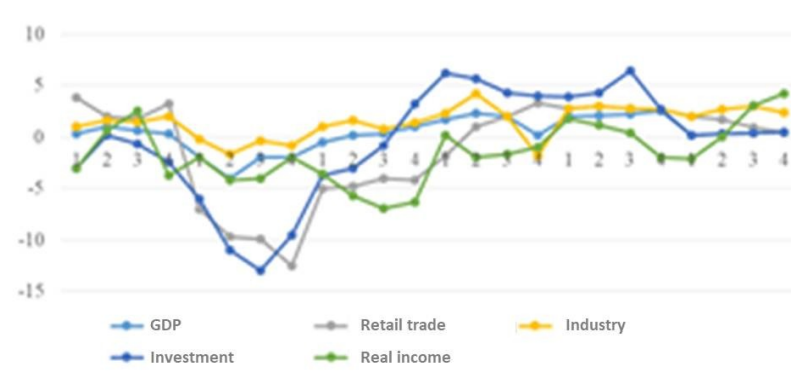

Figure 1 Quarterly indicative dynamics of key financial and economic indicators of the state of the national economy of the Russian Federation, 2014-19.

Figure 1 shows, that the 3rd quarter of 2015 became the most difficult period - the deepest "failures" in the dynamics of investment activity are related to this period. Throughout 2015, decline trends from production (due to capital outflow) to trade (due to inflation) are seen. The 
most significant reductions have: real incomes od population, investment activity and consumer demand.

The authors' research interest in consumer demand is due to its positioning as an identifying parameter of the current state of the national economy. The recovery and even some increase in consumption in 2017 was associated with active consumer lending, as population incomes continued to stagnate. The growth of consumer lending can be characterized as unsecured and even risky - the rise in price of goods due to the cost of loans was not offset by the comparable dynamics of disposable income, which formed a public demand for redistributive trends in social policy from the state, which compensates for consumer costs.

\section{STATEMENT OF THE PROBLEM AND METHODS}

In the context of this study, financial literacy is interpreted by the authors as a kind of synergistic combination of financial activity, awareness, knowledge, skills, goals and behavior, realized when making rational financial decisions in order to achieve financial well-being. The latter is a consequence of the influence of macroeconomic, geopolitical, social and financial factors on the living conditions of the population. The conditions themselves, in the same external environment, are subjected to the distortion by regional differences. Table 1 shows the social, financial and economic inequality due to the high concentration of the influence of agglomeration and institutional factors in the federal centers.

Table 1 Agglomeration and institutional factors of concentration of financial and economic indicators of the federal centers of the Russian Federation [1]

\begin{tabular}{|c|c|c|c|c|}
\hline $\begin{array}{c}\text { Share from the Russian } \\
\text { Federation, \% }\end{array}$ & Moscow & $\begin{array}{c}\text { Moscow and Moscow } \\
\text { region }\end{array}$ & St. Petersburg & $\begin{array}{c}\text { Saint Petersburg and } \\
\text { Leningrad region }\end{array}$ \\
\hline Population & 8.5 & 14 & 3.6 & 5 \\
\hline GRP & 21 & 26 & 5 & 7 \\
\hline Investments & 14.5 & 20 & 4.5 & 5 \\
\hline New housing supply & 5 & 16 & 5 & 6 \\
\hline Retail turnover & 15 & 23 & 5 & 8 \\
\hline Population income & 17 & 24 & 8 & 6 \\
\hline Deposits in banks & 35 & 41 & 6 & 6 \\
\hline Residential loans & 11 & 19 & 5 & 5 \\
\hline Budget income & 20 & 25 & 32 & 5 \\
\hline $\begin{array}{c}\text { Budget costs on the national } \\
\text { economy }\end{array}$ & 27 & 62 & 4 & 5 \\
\hline Budget costs on improvement & 56 & 27 & 4 & 5 \\
\hline $\begin{array}{c}\text { Budget costs on social } \\
\text { protection of the population }\end{array}$ & 21 & & & 5 \\
\hline
\end{tabular}

The revealed trends in financial redistribution, which concentrate a significantly more prosperous position of the population in federal centers in comparison with other regions of the country, have the following logic: allocated budget and investment resources into the capitals' economy have a higher turnover due to high business activity, reproducing a relatively high rate of development of these regions. Such a federal model of redistribution of financial flows forms differences in the level and quality of life of citizens of the capital region and other territories, which is approximated on all other regional trends: for example, residents of large regional cities live better than citizens, living in district centers and small settlements this is a sustainable social and financial system, which must be transformed into socially fair. Leaving political aspects outside the research vector, the authors see the following fundamental reasons for the existing differentiation:
Regional differences in the incomes of the population of federal centers and the average indicator for all other regions (figure 2 ).

The ongoing demographic imbalance, which has not yet been overcome even by the measures, that are being implemented in Russia - it is an increase in child allowances and expansion of maternity capital coverage of the birth of the first child. So, according to the Federal State Statistics Service of the Russian Federation (FSSS), the number of births in 2019 was 10.9 per 1000 people, while in 2018 this indicator was at 11.5 per 1000 people that is, there was a decrease in the birth rate by $5.2 \%$ (figure 3). Among the main reasons for such dynamics, experts name financial and economic uncertainty and declining real disposable incomes of the population (figure 
4).

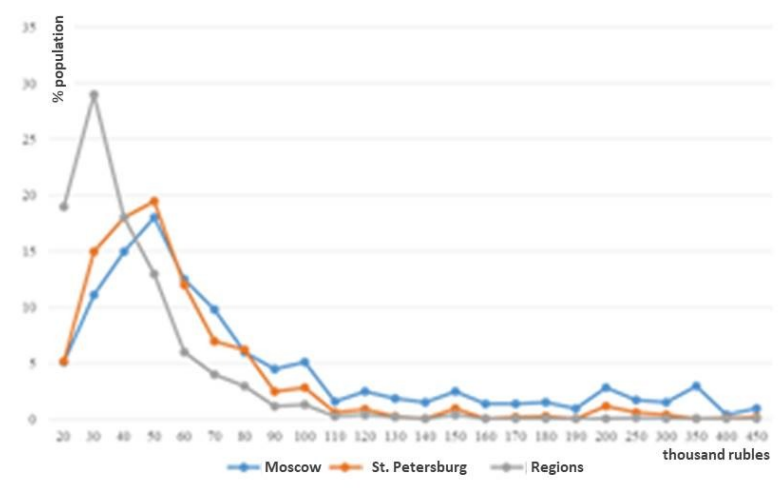

Figure 2 Income differences between federal centers and regions of the Russian Federation

As follows from the data in figure 2, income peaks among residents of federal centers and regions differ significantly: from 50 to 60 thousand rubles and 30 thousand rubles, respectively. Obviously, such a significant gap in the incomes of the country's residents from federal centers makes research in the field of financial behavior, including financial literacy, less informative, since people are in objectively different conjunctural conditions, which means, they solve different problems. For example, for many residents of the regions, investment financial instruments, that capital residents use or seek to use, are not interesting and potentially not available. Financial literacy - from the same category - many people with low incomes simply do not know the terms and their meaning from the sphere of insurance, investment, savings strategy. They do not use it.

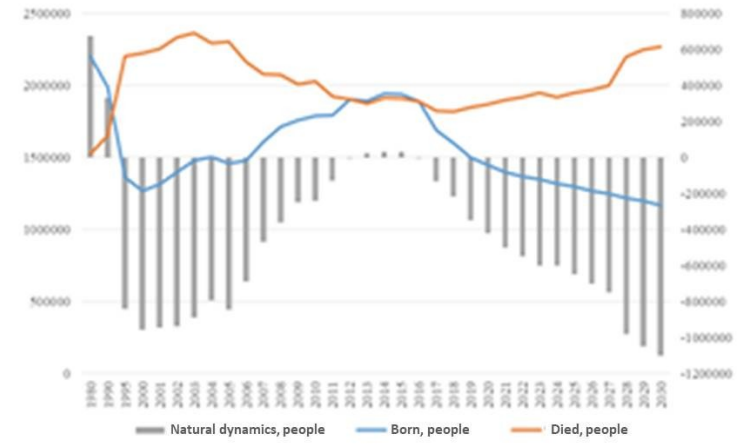

Figure 3 Demographic dynamics based on prediction

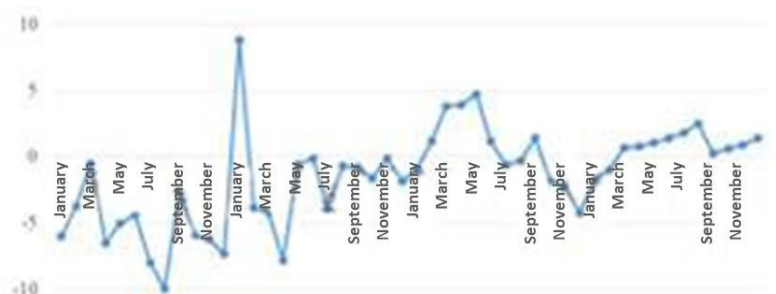

Figure 4 Dynamics of real disposable income of population, $\%[4,5]$

\section{RESEARCH RESULTS}

At the next stage of the study, the authors applied the method of sociological survey to assess the level of financial literacy and financial resource capacity. This method was chosen due to the lack of other methods of direct assessment of knowledge. The survey was conducted in public places - shopping centers of the listed cities in September - November 2019 by the unselected survey method - that is, respondents independently filled out questionnaires, regarding their identification (gender, age); financial and economic characteristics (attribution to the income group, availability of credit load and structure of costs) and issues, directly assessing financial knowledge. The basis of the questionnaire was the methodology of the Central Bank of the Russian Federation [4] and the National Agency for Financial Research (NAFR) [2]. The survey involved 5,842 people, quantitatively distributed approximately comparable across cities of the Sverdlovsk region (figure 5):

1) Berezovsky (718 people),

2) Bogdanovich (758 people),

3) Verkhnyaya Pyshma (761 people),

4) Yekaterinburg (847 people),

5) Irbit (710 people),

6) Kamensk Uralsky (745 people),

7) Nizhny Tagil (746 people),

8) Pervouralsk (757 people)

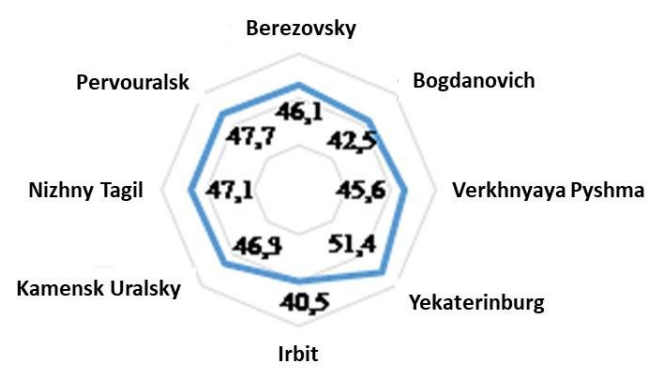

Figure 5 The results of the assessment of the level of FL of the population of the cities of the Sverdlovsk region, $\%$ As a hypothesis of the conducted study, the authors consider the possibility of presence of a correlation 
between the level of financial literacy and the income level of respondents, moreover, differences in incomes are determined by territorial belonging (table 2).

These tables confirm the authors' hypothesis that there is a direct correlation relationship between the level of income and the level of financial literacy of the population.

In addition to assessing the level of financial literacy, the authors analyzed the structure of costs of the population of different income groups (table 3). The authors believe, that the rationality of the allocation of financial resources by households is also a criterion indicator in assessing the financial literacy of the population, since the irrational allocation of income leads to huge debt load. As a criterion of a some optimality in assessing the rationality of costs, the authors adopted $45 \%$ of costs on current consumption in their total value.

Table 2 Correlation between income level and financial literacy of the population of Sverdlovsk region

\begin{tabular}{|c|c|c|}
\hline City name & The average salary, rubles & The level of financial literacy, $\%$ \\
\hline Yekaterinburg & 39830 & 51.4 \\
\hline Pervouralsk & 36694 & 47.7 \\
\hline Nizhny Tagil & 34140 & 47.1 \\
\hline Kamensk Uralsky & 33671 & 46.3 \\
\hline Berezovsky & 31794 & 46.1 \\
\hline Verkhnyaya Pyshma & 31156 & 45.6 \\
\hline Bogdanovich & 28167 & 42.5 \\
\hline Irbit & 27920 & 40.5 \\
\hline
\end{tabular}

Table 3 The structure of costs of the population of the Sverdlovsk region in the context of interval income groups, $\%$

\begin{tabular}{|c|c|c|c|c|c|}
\hline $\begin{array}{c}\text { The structure of costs by items, \% / } \\
\text { Interval income groups, thousand rubles }\end{array}$ & $12-20$ & $21-30$ & $31-40$ & $41-50$ & $>50$ \\
\hline Current consumption & 49.21 & 45.47 & 44.01 & 42.97 & 40.07 \\
\hline Obligatory payments & 20.68 & 19.62 & 19.25 & 17.75 & 16.98 \\
\hline Debt obligations & 25.29 & 26.44 & 28.56 & 29.13 & 24.91 \\
\hline Development costs & 2.37 & 3.41 & 4.22 & 4.26 & 8.71 \\
\hline Savings & 2.48 & 4.17 & 4.89 & 5.41 & 9.33 \\
\hline Total: & 100 & 100 & 100 & 100 & 100 \\
\hline
\end{tabular}

The most risky, from the standpoint of the structure of costs, as follows from the presented data, is the income group of 21-30 thousand rubles, spending more than $45 \%$ of all their costs on current consumption. Of course, the authors do not conclude, that this category has the least importance in assessing financial literacy: the reasons, why people spend a significant part of their income on current consumption, may be temporary difficulties, or, on the contrary, the opportunity not to save. However, the aspect of conducting studies to assess the level of financial literacy based on a comprehensively integrative approach can and should include criteria for the structure of costs, income groups, regions of residence and the activity of using digital financial services (figure 6).

In addition, measures are needed to popularize the use of digital financial services, which allow people to monitor the status of their financial resources on a daily basis and take into account

their financial situation when making financial decisions on disposal of income. These measures include efforts, taken by the National Agency for Financial Research (NAFR) and regional centers of financial literacy to conduct educational events: these are training seminars, conferences and just schools for illiterates for a wide variety of population groups throughout the country [2]. In addition, serious work was carried out by the NAFR on the formation and adaptation of existing world methods for assessing the level of financial literacy of the population, which allow to form predictive models of people's financial behavior for various, especially stressful external conditions: price shocks, hikes and slumps of the financial parameters of the national economy [13 ]. 


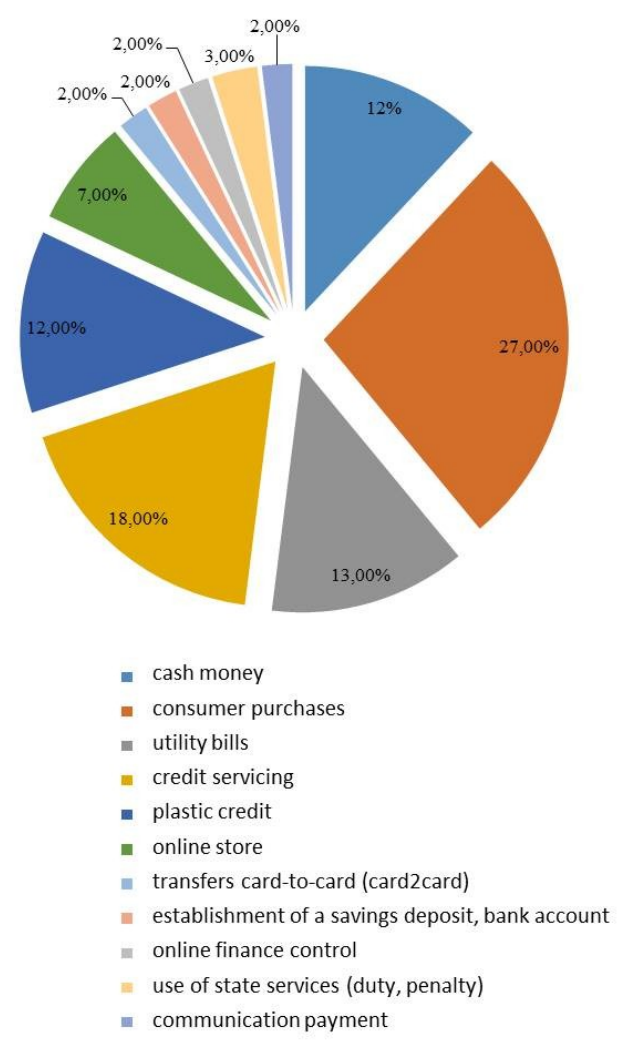

Figure 6 The structure of cash transactions of active DFS users

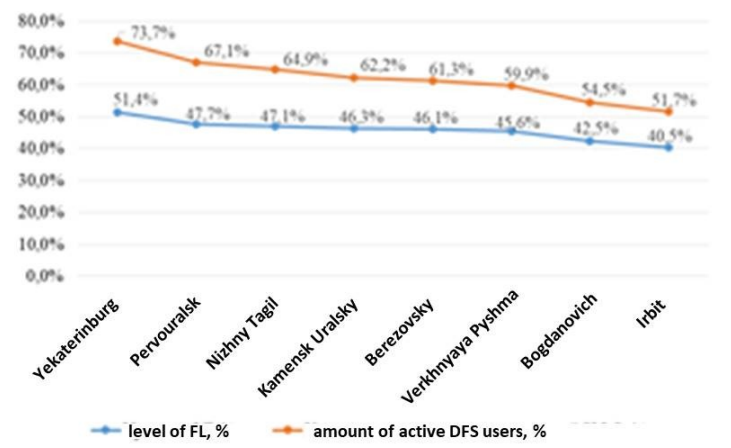

Figure 7 Comparison of trends in user activity of DFS and the level of financial literacy of the population of the Sverdlovsk region, $\%$

One of the most valuable results was a comparative analysis of the activity of people, using digital financial services, and assessments of the level of financial literacy: the correlation dependence is direct - the more actively the population uses DFS, the more financially literate it is (figure 7). It cannot be said, that the confirmation of this hypothesis is completely unexpected for the authors, but such convincing results are obtained, that expand the possibilities of increasing the level of financial knowledge through the practice of using a wide range of financial services and technologies, that the task of increasing the level of financial literacy seems not to be unachievable.

\section{CONCLUSION}

The final goal of research to assess the level of financial literacy is to increase the security of people when they make a wide range of financial decisions: life and property insurance, participation in investment projects and nonstate pension insurance programs, savings making - from the purchase of foreign currency to a share in a mutual investment fund and a number of others. Even simple purchases of essential goods are the subject of scientific research as the position of assessing the optimality of the structure of household financial resources [6] when predicting the behavior of the population as a borrower in case of hikes of activity from credit and micro-financial organizations. people themselves should be able to assess their credit position and not resort to credit to buy food [5]. International research in the field of consumer and financial behavior is not only actual, they are fundamental - it is a source of formation of strategies for many companies - manufacturers of consumer goods, food products, financial institutions - insurance, investment, trust, investment and others, that work with the population. Behavioral models, formed for different conditions, received international recognition - evidence of this is the 2017 Nobel Prize to R. Thaler for the work "New Behavioral Economics", which became popular in domestic research circles [7]. World scientific research touches on the issues of household financial planning [8], consumer finance [9], the debt load of the population and efforts to overcome income shortages and attract consumer lending $[10,11]$, the influence of digital, including financial services on risks, associated with the financial security of the population [12].

Following global trends in studying financial behavior and making financial decisions by people will allow to form actual data for conducting public policy in the social and financial spheres: to support demography, to stimulate social mortgages and a number of other areas of national projects and programs.

\section{REFERENCES}

[1] Doklad Zubarevich N.V. v Sovete Federatsii. Ofitsial'nyy You-tube kanal Soveta Federatsii RF // Elektronnyy resurs. https://www.youtube.com/watch? $\mathrm{v}=\operatorname{rgcS} 1 \mathrm{Izc}-\mathrm{M}$

[2] Ofitsial'nyy sayt analiticheskogo tsentra NAFI // Elektronnyy resurs: https://nafi.ru/

[3] Ofitsial'nyy sayt FSGS RF // Elektronnyy resurs // Dostup na 27.02.2020: https://gks.ru 
[4] Ofitsial'nyy sayt Tsentral'nogo Banka RF // Elektronnyy

resurs. https://www.cbr.ru/Ankets/MailForm.aspx?

PartID=fingram. Postupila v redaktsiyu: 10.10.2019 g.

[5] Razumovskaya Ye.A. Personal'noye finansovoye planirovaniye: teoriya i modelirovaniye protsessa // Deutschland, Saarbrucken: Palmarium Academic Publishing, 2016. - 313 s.

[6] Razumovskaya Ye.A., Razumovskiy D.YU. Podkhody k otsenke optimal'nosti struktur finansovykh resursov domokhozyaystv i finansovoy gramotnosti naseleniya // Finansy, №1, 2020. - S. 57 - 64

[7] Taler R. Novaya povedencheskaya ekonomika: pochemu lyudi narushayut pravila traditsionnoy ekonomiki. - M .: Izd-vo «E», 2017. - 368 s.

[8] Brounen D., Koedijk, K.G., Rachel A.J. Domashneye finansovoye planirovaniye i sberegatel'noye povedeniye. Zhurnal «Mezhdunarodnyye den'gi i finansy» № 69, 2016. - Rr. 95 - 107. DOI: 10.1016 / j.jimonfin.2016.06.011

[9] Berk M., Fray Dzh. Naskol'ko legko ponyat' potrebitel'skiye finansy? // Ekonomicheskiye pis'ma, № 177, 2019. - Rr. 1 - 4. DOI: 10.1016 / j.econlet.2019.01.004

[10] Kardachi A. Neravenstvo, zadolzhennost' domokhozyaystv i finansovaya nestabil'nost': agentnaya perspektiva // Zhurnal ekonomicheskogo povedeniya i organizatsii, № 149, 2018. - Rr. 434 - 458. DOI: $10.1016 /$ j.jebo. 2018.01 .010

[11] French D., Vin'ye S. Prichiny i posledstviya finansovogo napryazheniya domokhozyaystv: sistematicheskiy obzor. Mezhdunarodnyy obzor finansovogo analiza. - Tom 62, mart 2019 g., s. 150 156 str. Dostup: https://doi.org/10.1016/j.irfa.2018.09.008.

[12] Ozili P.K. Vliyaniye tsifrovykh finansov na finansovuyu dostupnost' i stabil'nost' // Borsa Istanbul Review, № 18 (4), 2018. - S. 329 - 340.

[13] Razumovskaya Ye., Isakova N., Razumovskiy D., Mokeyeva N., Kuklina Ye. (2016) Prinyatiye finansovykh resheniy naseleniyem: modelirovaniye protsessov i tendentsii // Indiyskiy nauchnotekhnicheskiy zhurnal 9 (46). DOI: 10.17485 / ijst / 2016 / v9i46 / 107570 